\title{
Food frequency consumption and lipoproteins serum levels in the population of an urban area, Brazil
}

Freqüência de consumo alimentar e níveis séricos de lipoproteínas na população de Cotia, SP, Brasil

Nélida Schmid Fornésa, Ignez Salas Martins ${ }^{b}$, Miguel Hernanc, Gustavo VelásquezMeléndez ${ }^{\mathrm{d}}$ and Alberto Ascherioc

aFaculdade de N utrição da U niversidade Federal de Goiás. G oiânia, GO, Brasil. ' D epartamento de N utrição da Faculdade de Saúde Pública da U niversidade de São Paulo. São Paulo, SP, Brasil. 'School of Public H ealth, H arvard U niversity. Boston, MA, USA. dU niversidade Federal de Minas Gerais. Belo Horizonte, M G, Brasil 


\section{Food frequency consumption and lipoproteins serum levels in the population of an urban area, Brazil* Freqüência de consumo alimentar e níveis séricos de lipoproteínas na população de Cotia, SP, Brasil}

\section{Nélida Schmid Fornésa, Ignez Salas Martins ${ }^{b}$, Miguel Hernanc, G ustavo Velásquez- Meléndez $^{d}$ and Alberto Ascherioc}

aFaculdade de Nutrição da U niversidade Federal de Goiás. Goiânia, GO, Brasil. ' D epartamento de Nutrição da Faculdade de Saúde Pública da Universidade de São Paulo. São Paulo, SP, Brasil. 'School of Public Health, Harvard U niversity. Boston, MA, USA. dU niversidade Federal de M inas Gerais. Belo Horizonte, MG, Brasil

\section{Keywords}

Food habits" . Food consumption". Cardiovascular diseases, prevention and control\#. Lipoproteins, HDL cholesterol, blood". Lipoproteins, LDL cholesterol, blood". Risk factors. Lipids, blood.

\begin{abstract}
Objective

To identify the association between food group consumption frequency and serum lipoprotein levels among adults.

Methods

The observations were made during a cross-sectional survey of a representative sample of men and women over 20 years old living in Cotia county, S. Paulo, Brazil. Data on food frequency consumption, serum lipids, and other covariates were available for 1,045 adults. Multivariate analyses adjusted by age, gender, body mass index, waist-to-hip ratio, educational level, family income, physical activity, smoking, and alcohol consumption were performed.

Results

Consumption of processed meat, chicken, red meat, eggs and dairy foods were each positively and significantly correlated with LDL-C, whereas the intake of vegetables and fruits showed an inverse correlation. Daily consumption of processed meat, chicken, red meat, eggs, and dairy foods were associated with $16.6 \mathrm{mg} / \mathrm{dl}, 14.5 \mathrm{mg} / \mathrm{dl}, 11.1 \mathrm{mg} / \mathrm{dl}, 5.8 \mathrm{mg} / \mathrm{dl}$, and $4.6 \mathrm{mg} / \mathrm{dl}$ increase in blood LDL-C, respectively. Increases of daily consumption of fruit and vegetables were associated with $5.2 \mathrm{mg} / \mathrm{dl}$ and $5.5 \mathrm{mg} / \mathrm{dl}$ decreases in LDL-C, respectively. Alcohol beverage consumption showed a significant positive correlation with HDL-C.

Conclusions

Dietary habits in the study population seem to contribute substantially to the variation in blood LDL and HDL concentrations. Substantially CHD risk reduction could be achieved with dietary changes.
\end{abstract}

*Based on the doctoral thesis presented to the "Faculdade de Saúde Pública, U niversidade de São Paulo, 1998". Presented at the IV "Congresso Brasileiro de Epidemiologia, Rio de Janeiro, 1998".

The publication of this article was subsidied by Fapesp (Process n. 00/01601-8).

Partially supported by grant from the "Coordenação de Aperfeiçoamento de Pessoal de Nível Superior - MECCAPES (BEX2921/95); Conselho N acional de Desenvolvimento Científico e Tecnológico - CN Pq (410427/89-6) and Fundação de Apoio à Pesquisa de São Paulo - Fapesp (Processo n 91/0820-7)

Submitted on 25/8/1999. Reviewed on 29/2/2000. Approved on 21/3/2000. 


\section{Descritores}

Hábitos alimentares ${ }^{\#}$. Consumo de alimentos $^{\#}$. Doenças cardiovasculares, prevenção e controle ${ }^{\#}$. Lipoproteínas do colesterol HDL, sangue ${ }^{\#}$. Lipoproteínas do colesterol $L D L$, sangue $e^{\#}$. Fatores de risco. Lipídios, sangue.

\section{Resumo}

\section{Objetivo}

Identificar a associação entre a freqüencia de consumo de diferentes grupos de alimentos e níveis de lipídios séricos de adultos.

\section{Métodos}

As observações pertencem a um estudo transversal e correspondem a uma amostra representativa de 1.045 adultos de ambos os sexos, de 20 anos ou mais, residentes no município de Cotia, SP, Brasil. Foram determinados a ingestão de alimentos pela freqüência de consumo alimentar, níveis de lipídios séricos e outras variáveis. Foram elaborados modelos de regressão linear múltipla (stepwise forward) para LDL-C e HDL-C, ajustados por: idade, sexo, índice de massa corpórea, relação cintura quadril, nível educacional, renda familiar, atividade física, tabagismo $e$ etilismo.

\section{Resultados}

O consumo de carnes (bovina, suína, aves, vísceras e carnes processadas), leite e derivados e ovos correlacionou-se positiva e significativamente com LDL-C. $O$ consumo de frutas e hortaliças mostraram correlação inversa e significativa. $O$ consumo de: carnes de aves, carnes vermelhas, ovos e leite e derivados foram associados com um aumento na $\mathrm{LDL}-\mathrm{C}$ de $16,6 \mathrm{mg} / \mathrm{dl}, 14,5 \mathrm{mg} / \mathrm{dl}, 11,1 \mathrm{mg} / \mathrm{dl}, 5,8 \mathrm{mg}$ / $\mathrm{dl}$, e 4,6 $\mathrm{mg} / \mathrm{dl}$, respectivamente. $O$ aumento no consumo de frutas e hortaliças foi correlacionado com uma redução de $5,2 \mathrm{mg} / \mathrm{dl}$ e $5,5 \mathrm{mg} / \mathrm{dl}$ nos níveis de $\mathrm{LDL}-\mathrm{C}$, respectivamente. $O$ consumo de bebidas alcoólicas se correlacionou positiva e significativamente com a fração $H D L-C$.

\section{Conclusões}

Na população brasileira estudada observou-se que os hábitos alimentares parecem contribuir para as variações na concentração dos lipídios séricos de LDL-C e HDLC. Redução nos riscos de doenças cardiovasculares podem ser alcançadas por meio de controle dietético.

\section{INTRO DUCTIO N}

The longstanding view about the relationship between diet and coronary heart disease (CHD) has been strongly based on the observation that serum LDL and HDL cholesterol levels are CHD risk predictors. ${ }^{21}$ Although several controlled experiments have estimated the effects of specific fatty acids on blood lipids, there is still a lack of information about the importance of diet in determining HDL and LDL concentrations in free living populations. ${ }^{21}$

The purpose of this cross-sectional study was to examine the association between specific food consumption frequencies and low-density lipoprotein (LDL) and high-density lipoprotein (HDL) cholesterol concentration levels among adults in S. Paulo, Brazil. ${ }^{7}$

\section{METHODS}

\section{Population}

A standardized questionnaire was administered to a representative sample of non-institutionalized adults $(n=1,328)$ aged 20 years or more living in the town of Cotia, Greater São Paulo, Brazil. The survey methodology was based in Singer et al. ${ }^{18}$
The observations were collected during a cross-sectional assessment.

The questionnaire consisted of three parts: a $D e$ mographic Section to record the subjects' age, gender, occupation, marital status, educational background, family income, and family size; a Clinical, Anthropometric and Biochemical section; and a Food Frequency Questionnaire Section. The individuals were interviewed at the local health centers and community health centers, and each interviewer followed a basically structured interview protocol.

From the 1,049 adults interviewed in the survey, people who did not give complete information on social-demographic status $(n=1)$, did not fulfill the biochemistry requirements $(n=2)$ and/ or did not answer the food frequency questionnaire $(n=1)$ were excluded from the analysis. Only 4 subjects $(0.3 \%)$ were excluded as data was missing on at this last variable. Subjects who reported having cardiovascular disease, diabetes and/or were on medication that affect blood lipids were also excluded. Data on food consumption frequency, serum lipids, and other covariates were available for 1,045 adults. 
Educational level was divided into five categories and family income was classified into in four categories, based on the number of minimal wages (approximately US $\$ 100.00=1$ minimal wage)

\section{Clinical, anthropometric and biochemistry assessment methods}

The general examination routine is described elsewhere. ${ }^{12}$ Subjects' height, weight, waist and hip circumferences were recorded. Body mass index (BMI, $\mathrm{kg} \mathrm{per} \mathrm{m}^{2}$ ) and waist-to-hip ratio were calculated. Information on lifestyle, physical activity, smoking and alcohol consumption were also gathered. Daily physical activity was assessed with six questions and respondents were asked about their occupation (type of work) and whether they engage in any leisure-tioe physical activities or exercises, such as running, gardening or walking. Activities were recorded in resting metabolic rate (BMR) equivalents, taking into account frequency, intensity, and duration of the physical activity. The total weekly time spent per activity was calculated according to the activity levels suggested by the FAO/ WHO/UN (WHO, 1985). ${ }^{16}$ Each subject was allocated into one of the three physical activity categories: mild, medium-to-heavy, and heavy.

Participants' smoking status was classified according to the number of cigarettes smoked per day. Only individuals smoking ten or more cigarettes per day were considered smokers. To identify alcohol consumption, four questions extracted from the CAGE questionnaire ${ }^{13}$ were used. Individuals who answered two or more questions positively were considered alcohol abusers.

Enzymatic methods were used to measure serum lipids. Blood samples were collected at the Cotia health center after an overnight fasting (12 hours or more). Samples were sent to the São Paulo University Hospital laboratory where they were analyzed. Total cholesterol (TC) and HDL-C were determined by auto-analyzer, using Boehringer Manhein Merk enzymatic method. Triglycerides (TG) were determined by enzymatic calorimetric methods using commercial kits - Cholesterol Cod-Ana Labtest ${ }^{\circledR}$. LDL-C was calculated according to the Friedewald equation: $($ LDL-C $)=(\mathrm{TC})-($ HDL-C $)-(\mathrm{TG}) / 5$.

\section{Assessment of food consumption frequency}

A twelve-month retrospective food frequency questionnaire was used to determine food consumption frequency. A staff trained member or a dietitian interviewed each participant using a tool previously as- sessed in the pilot study. The food list consisted of forty-four Brazilian foods. The questionnaire had open-end questions to allow the introduction of food items not included in the list. Respondents were asked to average their food consumption over the year by indicating how often each kind of food was consumed. Consumption frequency for a 365-day period was categorized into seven different categories for each food item: 0 , never; 0.03 , once a month or less; 0.08 , two to three times a month; 0.22 , one to two times a week; 0.50 , three to four times a week; 0.79 , five to six times a week; and 1 , once a day. For each food group, consumption frequency was calculated by adding the reported frequency for each food items.

\section{Statistical analysis}

The association between serum lipids and food consumption and non-dietary factors was first assessed with univariate analyses. Spearman-correlation coefficients were used to estimate the association between individual food item consumption frequency and serum lipids concentration. Multivariate linear regression was used to estimate the association between food consumption frequency and serum blood lipoproteins, adjusted by other covariates. Serum lipoproteins (LDL-C and HDL-C) levels were the dependent variables in two separate linear regression models which included age, body mass index, waist-to-hip ratio and individual food consumption as continuous variables, and gender, educational level, family income, physical activity, smoking status, alcohol consumption as categorical variables. LDL-C and HDL-C continuous variables were adjusted for age, gender and versus multivariate. The variable body mass index and waistto-hip ratio were divided by the corresponding standard deviation. Foods were also grouped into eleven major food groups as showed in Table 1 .

All probability values are two-tailed. Results were defined as statistically significant for a value of $\mathrm{p}<0.05$. Analyses were performed using the Statistical Analysis System (SAS), UNIX 6.12 version.

\section{RESU LTS}

Demographic and risk factors characteristics of the study population are showed in Table 2 .

Almost one third of the subjects reported as schooling years to have not graduated from grade school $(n=259)$, $23.8 \%$ had graduated from grade school, and $13.4 \%$ were illiterate. $42 \%$ referred a family income between one and five minimum wages, and only $14.6 \%$ reported a monthly family income greater than 10 minimum wages. 
Table 1 - Reported using foods by the study population included in the modeling process.

\begin{tabular}{|c|c|}
\hline Food groups & Foods included in the food group \\
\hline Alcohol beverage & beer, wines, firewater of sugar cane, and others spirit \\
\hline Dairy & milks, cheeses, butter, and yogurt \\
\hline Vegetables & $\begin{array}{l}\text { water-cress, lettuce, endivel, chicory, cabbage, pumpkin, summer squash, beetroot, carrot, chayote, } \\
\text { fruit of the jiloeiro, corn, cucumber, okra, tomato, French bean, kale, cauliflower, radish, swiss } \\
\text { chard, wild chicory, spinach, potato, sweet potato, and cassava }\end{array}$ \\
\hline Fruits & bananas, oranges, apples, papaya, watermelon, melon, pear, and tangerine \\
\hline Red meats & bovine meats, pork meats \\
\hline Chicken & chicken with skin \\
\hline Eggs & chicken whole eggs \\
\hline $\begin{array}{l}\text { Processed meats, luncheon } \\
\text { meats and internal organs }\end{array}$ & $\begin{array}{l}\text { italian sausage, salami, ham, high fat ham, liver (from poultry and bovine), chicken heart, } \\
\text { chicken gizzard, and kidney }\end{array}$ \\
\hline & atlantic fish; e.g., sardine, and river fish \\
\hline $\begin{array}{l}\text { Breads and cereals } \\
\text { Beans }\end{array}$ & $\begin{array}{l}\text { from refined grain products: rice, cracker, biscuit, breads, macaroni, corn flour, and corn meal } \\
\text { red and black beans }\end{array}$ \\
\hline
\end{tabular}

Table 2 - Demographic and risk factor characteristics of the study population. Cotia, S. Paulo, Brazil.

\begin{tabular}{|c|c|c|c|c|}
\hline \multirow[t]{2}{*}{ Characteristics } & \multicolumn{2}{|c|}{ Gender } & \multirow[t]{2}{*}{ Total } & \multirow[t]{2}{*}{$(\%)$} \\
\hline & Female & Male & & \\
\hline Number of participants & 615 & 430 & 1045 & 100 \\
\hline $\begin{array}{l}\text { Age categories (years): } \\
20-29 \\
30-39 \\
40-49 \\
50-59 \\
>60 \\
\left.>01 \mathrm{Ka} / \mathrm{m}^{2}\right)\end{array}$ & $\begin{array}{r}165 \\
203 \\
122 \\
60 \\
65\end{array}$ & $\begin{array}{r}90 \\
147 \\
98 \\
54 \\
41\end{array}$ & $\begin{array}{l}255 \\
350 \\
220 \\
114 \\
106\end{array}$ & $\begin{array}{l}24.4 \\
33.5 \\
21.1 \\
10.9 \\
10.1\end{array}$ \\
\hline $\begin{array}{c}<25 \\
25-27 \\
>27 \\
W H R^{b}\end{array}$ & $\begin{array}{r}338 \\
94 \\
183\end{array}$ & $\begin{array}{r}280 \\
60 \\
90\end{array}$ & $\begin{array}{l}618 \\
154 \\
273\end{array}$ & $\begin{array}{l}59.2 \\
14.7 \\
26.1\end{array}$ \\
\hline $\begin{array}{l}<0.95 \\
\geq 0.95 \\
<0.80 \\
\geq 0.80\end{array}$ & $\begin{array}{c}- \\
- \\
169 \\
446\end{array}$ & $\begin{array}{c}360 \\
70 \\
- \\
-\end{array}$ & $\begin{array}{r}360 \\
70 \\
169 \\
446\end{array}$ & $\begin{array}{r}34.4 \\
6.7 \\
16.2 \\
42.7\end{array}$ \\
\hline $\begin{array}{l}\text { Physical activityc } \\
\text { Light activity } \\
\text { Moderate activity } \\
\text { Intense activity }\end{array}$ & $\begin{array}{r}236 \\
284 \\
95\end{array}$ & $\begin{array}{r}173 \\
161 \\
96\end{array}$ & $\begin{array}{l}409 \\
445 \\
191\end{array}$ & $\begin{array}{l}39.0 \\
42.5 \\
18.5\end{array}$ \\
\hline $\begin{array}{l}\text { Yes } \\
\text { No }\end{array}$ & $\begin{array}{l}165 \\
450\end{array}$ & $\begin{array}{l}187 \\
243\end{array}$ & $\begin{array}{l}352 \\
693\end{array}$ & $\begin{array}{l}33.6 \\
66.4\end{array}$ \\
\hline $\begin{array}{l}\text { Ethylisme } \\
\text { Yes } \\
\text { No } \\
\text { LDL-C }(\mathrm{mg} / \mathrm{dL})\end{array}$ & $\begin{array}{r}6 \\
609\end{array}$ & $\begin{array}{r}87 \\
343\end{array}$ & $\begin{array}{r}93 \\
952\end{array}$ & $\begin{array}{r}8.9 \\
91.1\end{array}$ \\
\hline $\begin{array}{c}<130 \\
130-159 \\
\geq 160 \\
\text { HDL-C } C^{g}(\mathrm{mg} / \mathrm{dL})\end{array}$ & $\begin{array}{r}415 \\
121 \\
79\end{array}$ & $\begin{array}{r}298 \\
86 \\
46\end{array}$ & $\begin{array}{l}713 \\
207 \\
125\end{array}$ & $\begin{array}{l}68.2 \\
19.8 \\
12.0\end{array}$ \\
\hline $\begin{array}{l}\leq 35 \\
>35\end{array}$ & $\begin{array}{l}121 \\
494\end{array}$ & $\begin{array}{l}100 \\
330\end{array}$ & $\begin{array}{l}221 \\
824\end{array}$ & $\begin{array}{l}22.1 \\
78.9\end{array}$ \\
\hline
\end{tabular}

a Body $M$ ass Index $\left(\mathrm{kg} / \mathrm{m}^{2}\right)$

b Waist-to-hip ratio

c Calculate by: type of work activity and other physical activity.

d Smoker $\geq 10$ cigarettes/ day

e Ethylism $=$ CAGE questionnaire ${ }^{13}$

f Serum Low Density Lipoprotein-Cholesterol level

g Serum High Density Lipoprotein-Cholesterol level

The Spearman correlation coefficients $\left(\mathrm{r}_{\mathrm{s}}\right)$ between LDL-C level $(\mathrm{mg} / \mathrm{dl})$ and food consumption frequency were significantly positive for dairy $\left(\mathrm{r}_{\mathrm{s}}=0.09\right.$; $\mathrm{p} \leq 0.01)$, red meat $\left(\mathrm{r}_{\mathrm{s}}=0.15 ; \mathrm{p} \leq 0.001\right)$, chicken $\left(r_{s}=0.10 ; p \leq 0.01\right)$, eggs $\left(r_{s}=0.10 ; p \leq 0.01\right)$, and processed meat $\left(r_{s}=0.08 ; p \leq 0.05\right)$, while significantly negative for vegetables $\left(r_{s}=-0.11 ; p \leq 0.001\right)$, fruits $\left(r_{s}=-0.05 ; \mathrm{p} \leq 0.01\right)$, and fish $\left(r_{s}=-0.08 ; \mathrm{p} \leq 0.05\right)$.

Spearman correlation coefficients $\left(r_{s}\right)$ between HDL-C level (mg/dl) and the food consumption frequency were significantly positive for alcohol $\left(r_{s}=0.08 ; p \leq 0.01\right)$ and significantly negative for processed meat $\left(r_{s}=-0.06 ; p \leq 0.05\right)$, and beans $\left(r_{s}=-0.07\right.$; $\mathrm{p} \leq 0.05)$.

The results of the linear regression analyses are showed in Table 3 and 4 . The association between serum lipoproteins and food consumption frequency for each of the eleven food groups were examined separately. The consumption of dairy foods adjusted for age and gender showed a significant positive association with LDL-C $\left(\beta_{\mathrm{i}}=4.86\right)$. There was no change in the observed association after adjusting for $\mathrm{BMI} / \mathrm{SD}, \mathrm{WHR} / \mathrm{SD}$, educational level, family income, physical activity, smoking, alcohol abuse or food groups. LDL-C concentration had an inversely significant association with consumption of fruits and vegetables in all models, whereas it was strongly positively associated with red meat consumption. The relationship between LDL-C and chicken consumption frequency showed a stronger positive association $\left(\beta_{\mathrm{i}}=18.08\right)$ than with red meat when potential confounders were adjusted $\left(\beta_{\mathrm{i}}=14.47\right)$. Egg consumption had a significant positive association with LDL-C. Processed meat consumption showed a positive association with LDL$\mathrm{C}$ serum levels even after controlling confounders factors $\left(\beta_{\mathrm{i}}=16.55\right)$. Consumption of fish, cerealsbreads, beans, and alcohol showed to have a nonsignificant negative association, even after adjusting for potential confounders (Table 3).

There was a non-significant inverse association between consumption of the dairy, fruits, vegetable, red meat, chicken, eggs, processed meat, fish and cereals-breads group foods and HDL-C. Beans con- 
Table 3 - Regression coefficients - $\beta_{1}$ (95\% confidence interval) of food frequency consumption of food groups in linear models with LDL-Cholesterol as dependent variable.

\begin{tabular}{|c|c|c|c|}
\hline \multicolumn{4}{|c|}{$\begin{array}{l}\text { HDL-Cholesterol } \\
\text { (mg/dl) }\end{array}$} \\
\hline $\begin{array}{l}\text { Food and } \\
\text { food Groups }\end{array}$ & $\begin{array}{l}\text { Age - Sex } \\
\text { adjusted }\end{array}$ & Multivariate & $\begin{array}{l}\text { Multivariate - } \\
\text { simultaneous }^{b}\end{array}$ \\
\hline Dairy & $4.86^{* *}$ & -0.57 & -0.31 \\
\hline Fruits & $\begin{array}{l}(1.57 \text { to } 8.15) \\
-5.49^{* *}\end{array}$ & $\begin{array}{c}(-1.62 \text { to } 0.52) \\
-0.17\end{array}$ & $(-1.39$ to 0.77$)$ \\
\hline tivuits & $(-9.61$ to -1.37$)$ & $(-1.48$ to 1.14$)$ & $(-1.48$ to 1.22$)$ \\
\hline Vegetable & $-3.21^{* *}$ & -0.25 & 0.01 \\
\hline Red meat & $\begin{array}{l}(-5.61 \text { to }-0.82) \\
10.69^{* * *}\end{array}$ & $\begin{array}{c}(-1.04 \text { to } 0.46) \\
0.26\end{array}$ & $\begin{array}{l}(-0.79 \text { to } 0.81) \\
0.25\end{array}$ \\
\hline & (6.75 to 14.63$)$ & $(-0.99$ to 1.51$)$ & $(-0.99$ to 1.49$)$ \\
\hline Chicken & $18.08^{* * *}$ & -1.05 & -0.56 \\
\hline Eggs & $6.08^{*}$ & $\begin{array}{c}(-3.94 \text { to } 1.84) \\
-1.45\end{array}$ & $\begin{array}{c}(-3.44 \text { to } 2.32) \\
-1.39\end{array}$ \\
\hline Processed Meat & (1.01 to 11.15$)$ & $(-3.03$ to 0.13$)$ & $(-2.97$ to 0.19$)$ \\
\hline & (7.40 to 31.92$)$ & $(-5.81$ to 1.69$)$ & $(-6.44$ to 1.10$)$ \\
\hline Fish & $\begin{array}{c}-16.55 \\
(-41.61 \text { to } 8.51)\end{array}$ & $\begin{array}{c}-3.09 \\
(-10.72 \text { to } 4.54)\end{array}$ & $12{ }^{-4.75}$ \\
\hline Cereals-Bread & 0.36 & $-1.07^{*}$ & -0.65 \\
\hline Beans & $\begin{array}{c}(-2.44 \text { to } 3.16) \\
-2.21\end{array}$ & $\begin{array}{c}(-1.94 \text { to }-0.20) \\
-3.33^{* *}\end{array}$ & $\begin{array}{c}(-1.56 \text { to } 0.26) \\
-3.22^{* *}\end{array}$ \\
\hline cento & $(-9.61$ to 5.19$)$ & $(-5.61$ to -1.05$)$ & $(-5.57$ to -0.87$)$ \\
\hline Alcohol Beverage & $\begin{array}{c}-2.48 \\
(-9.44 \text { to } 4.48)\end{array}$ & $\begin{array}{c}6.95^{* * *} \\
(4.32 \text { to } 9.58)\end{array}$ & $\begin{array}{c}7.23^{* * *} \\
(4.59 \text { to } 9.87)\end{array}$ \\
\hline
\end{tabular}

a Model includes age (continuous variable); sex (male=1); body mass index/standard deviation (continuous variable); waist to hip ratio/standard deviation (continuous variable); educational level (five categories); family income (four categories); physical activity (three categories); smoking habits (smoker $=\geq 10$ cigarettes per day); Ethylism (alcoholic by CAGE questionnaire ${ }^{13}$ ).

b Additionally adjusted for food frequency consumption of food and food groups (continuous variable).

$* \mathrm{p} \leq .05 ; * * \mathrm{p} \leq .01 ; * * * \mathrm{p} \leq .001$

Table 4 - Regression coefficients - $\beta_{1}(95 \%$ confidence interval) of food frequency consumption of food groups in linear models with HDL-Cholesterol as dependent variable.

\begin{tabular}{|c|c|c|c|}
\hline \multirow[b]{2}{*}{$\begin{array}{l}\text { Food and } \\
\text { food Groups }\end{array}$} & \multicolumn{2}{|c|}{$\begin{array}{l}\text { HDL-Cholesterol } \\
\text { (mg/dl) }\end{array}$} & \multirow[b]{2}{*}{$\begin{array}{l}\text { Multivariate - } \\
\text { simultaneous }\end{array}$} \\
\hline & $\begin{array}{l}\text { Age - Sex } \\
\text { adjusted }\end{array}$ & Multivariate ${ }^{a}$ & \\
\hline Dairy & \multirow{16}{*}{$\begin{array}{c}-0.59 \\
(-1.09 \text { to } 0.45) \\
-0.47 \\
(-1.79 \text { to } 0.85) \\
-0.13 \\
(-0.88 \text { to } 0.62) \\
0.18 \\
(-1.07 \text { to } 1.43) \\
-1.54 \\
(-4.51 \text { to } 1.43) \\
-1.18 \\
(-2.77 \text { to } 0.41) \\
-2.45 \\
(-6.31 \text { to } 1.41) \\
-3.22 \\
(-11.08 \text { to } 4.64) \\
-0.71 \\
(-1.59 \text { to } 0.17) \\
-2.92^{*} \\
(-5.23 \text { to }-0.61) \\
5.41^{* * *} \\
(3.25 \text { to } 7.57)\end{array}$} & -0.57 & \multirow{16}{*}{$\begin{array}{c}-0.31 \\
(-1.39 \text { to } 0.77) \\
-0.13 \\
(-1.48 \text { to } 1.22) \\
0.01 \\
(-0.79 \text { to } 0.81) \\
0.25 \\
(-0.99 \text { to } 1.49) \\
-0.56 \\
(-3.44 \text { to } 2.32) \\
-1.39 \\
(-2.97 \text { to } 0.19) \\
-2.67 \\
(-6.44 \text { to } 1.10) \\
-4.75 \\
(-12.38 \text { to } 2.88) \\
-0.65 \\
(-1.56 \text { to } 0.26) \\
-3.22^{* *} \\
(-5.57 \text { to }-0.87) \\
7.23^{* * *} \\
(4.59 \text { to } 9.87)\end{array}$} \\
\hline Fruitc & & $(-1.62$ to 0.52$)$ & \\
\hline rruts & & $(-1.48$ to 1.14$)$ & \\
\hline Vegetable & & -0.25 & \\
\hline Dod mot & & $(-1.04$ to 0.46$)$ & \\
\hline Red meat & & $\begin{array}{c}0.26 \\
(-0.99 \text { to } 1.51)\end{array}$ & \\
\hline Chicken & & -1.05 & \\
\hline Fagc & & $(-3.94$ to 1.84$)$ & \\
\hline Lygs & & $(-3.03$ to 0.13$)$ & \\
\hline Processed Meat & & $\begin{array}{c}-2.06 \\
(-5.81 \text { to } 169)\end{array}$ & \\
\hline Fish & & -3.09 & \\
\hline Cereals-Bread & & $\begin{array}{c}(-10.12 \text { to } 4.54) \\
-1.07^{*}\end{array}$ & \\
\hline & & $(-1.94$ to -0.20$)$ & \\
\hline Beans & & $\begin{array}{c}-3.33^{* *} \\
(-5.61 \text { to }-1.05)\end{array}$ & \\
\hline Alcohol Beverage & & $6.95^{* * *}$ & \\
\hline & & (4.32 to 9.58 ) & \\
\hline
\end{tabular}

a Model includes age (continuous variable); sex (male=1); body mass index/standard deviation (continuous variable); waist to hip ratio/standard deviation (continuous variable); educational level (five categories); family income (four categories); physical activity (three categories); smoking habits (smoker $=\geq 10$ cigarettes per day); Ethylism (alcoholic by CAGE questionnaire ${ }^{13}$ ).

b Additionally adjusted for food frequency consumption of food and food groups (continuous variable).

$* \mathrm{p} \leq .05 ; * * \mathrm{p} \leq .01 ; * * * \mathrm{p} \leq .001$

sumption frequency had a significant negative association with HDL-C levels. Regarding this same lipoprotein, alcohol consumption showed also a sig- nificant positive association after gender $\left(\beta_{\mathrm{i}}=5.41\right)$, multivariate $\left(\beta_{\mathrm{i}}=6.95\right)$, and $\left(\beta_{\mathrm{i}}=7.23\right)$ multivariate simultaneous adjustments (Table 4 ). 
To assess the public health importance of these findings, potential reductions in the population LDL-cholesterol that could be achieved with dietary changes were calculated. To facilitate the direct comparison of the observed association between consumption frequency in each food group $\left(\mathrm{f}_{\mathrm{i}}\right)$ and possible changes in LDL-C levels, ten different hypothetical diets were designed, with all six food groups represented (fruits, vegetables, red meat, chicken, eggs and dairy).

For each assumption, the calculation was based on the LDL-C multivariate-simultaneous regression coefficient $-\beta_{\mathrm{i}}$ - seen in Table 3 , using actual population distributions and comparing individuals in upper versus lower score decile from the consumption frequency code. The possible effect on LDL-C levels was calculated according to the annual variation of each food groups' consumption frequency. To facilitate this calculation, fruits, vegetables, red meat and chicken groups consumption frequency were the only modified, and a fixed consumption frequency for the others food groups was maintained. To simplify, interpretation was performed as follows: in the two different hypothetical diets (level 1 and level 10), actual numbers obtained in the study (Table 3 ) and food consumption frequency code were used (a year of 365 days $=1$ and proportionally coded to the number of days in each category).

Diet level 1:

$44.40+[(-5.18 \times 0.22)+(-5.47 \times 0.22)+(11.05 \times 1.00)$ $+(14.47 \times 0.79)+(5.82 \times 0.22)+(4.64 \times 1.00)]=$ $70.46 \mathrm{mg} / \mathrm{dl}$

Diet level 10:

$44.40+[(-5.18 \times 7.00)+(-5.47 \times 6.00)+$ $(11.05 \times 0.08)+(14.47 \times 0.08)+(5.82 \times 0.22)+$ $(4.64 \times 1.00)]=-16.71 \mathrm{mg} / \mathrm{dl}$
From this calculation, LDL-C variation was obtained, which represent the possible increase or decrease in LDL$\mathrm{C}$ in milligrams per deciliter $(\mathrm{mg} / \mathrm{dl})$. Table 5 shows the LDL-C variation obtained from ten different food diets.

\section{DISCUSSION}

Four decades ago, numerous investigators observed considerable differences in serum cholesterol levels of different population groups. It has been observed that in many so-called developing countries the average blood cholesterol level was lower than in the most developed countries. ${ }^{9}$ In developing countries it is observed an increase in the energetic density of diets, mainly due to an elevation in fat consumption, sedentary lifestyle and a consequent growth in the prevalence of obesity. Thus, this component of the current nutritional transition represents a crisis demanding both recognition and action. Some regional problems in Brazil are closer to those found in the United States, where poor people suffer more from dietary excesses than the rich, with noncomunicable diseases, cardiovascular and other diseases mortality being higher among the poor. ${ }^{14}$ There was a change in the prevalence of coronary heart disease (CHD) in the Brazilian population, and today CHD is a major cause of death. ${ }^{11}$ High plasma cholesterol is a well-established risk factor. The relationship between diet and CHD strongly relies on the fact that serum LDL and HDL cholesterol levels are good predictors of CHD risk (Willett, ${ }^{21}$ 1998). It has been more than 100 years that cholesterol is known as a main component of the atheromatous plaque. Individuals with high serum cholesterol levels have a greater risk of developing CHD than those with low serum cholesterol. The Framingham Heart Study has documented several classes of agents that contribute to cardiovascular disease. Serum total cholesterol atherogenic potential has been showed to derive from the low density lipoprotein cholesterol (LDL-C) fraction which was found

Table 5 - Estimated variation according to hypothetical food frequency consumption by the regression coefficient $\beta_{1}$ after adjusted by multivariate simultaneous ${ }^{\mathrm{a}}$.

\begin{tabular}{|c|c|c|}
\hline Level & Diet & LDL-Cb Variation \\
\hline 1 & Int. $^{c}+\left[\left(\right.\right.$ FRU $\left.\times f_{4}\right)+\left(\right.$ VEG $\left.\times f_{4}\right)+\left(\right.$ RMT $\left.\left.\times f_{7}\right)+\left(C H I K \times f_{6}\right)+\left(E G G \times f_{4}\right)+\left(D A I \times f_{7}\right)\right]$ & 70.46 \\
\hline 2 & Int. $^{c}+\left[\left(\right.\right.$ FRU $\left.\times f_{5}\right)+\left(\right.$ VEG $\left.\times f_{5}\right)+\left(\right.$ RMT $\left.\left.\times f_{6}\right)+\left(C H I K \times f_{5}\right)+\left(E G G \times f_{4}\right)+\left(D A I \times f_{7}\right)\right]$ & 60.95 \\
\hline 3 & Int. $^{c}+\left[\left(\right.\right.$ FRU $\left.\times f_{6}\right)+\left(\right.$ VEG $\left.\times f_{6}\right)+\left(\right.$ RMT $\left.\times f_{5}\right)+\left(\right.$ CHIK $\left.\times f_{4}\right)+\left(E G G \times f_{4}^{4}\right)+\left(\right.$ DAI $\left.\left.\times f_{7}\right)\right]$ & 50.61 \\
\hline 4 & Int. $^{c}+\left[\left(\right.\right.$ FRU $\left.\times f_{7}\right)+\left(\right.$ VEG $\left.\times f_{7}\right)+\left(\right.$ RMT $\left.\left.\times f_{4}\right)+\left(C H I K \times f_{3}\right)+\left(E G G \times f_{4}\right)+\left(D A I \times f_{7}\right)\right]$ & 43.26 \\
\hline 5 & Int. $^{c}+\left[\left(\right.\right.$ FRU $\left.\times f_{8}\right)+\left(\right.$ VEG $\left.\times f_{9}\right)+\left(\right.$ RMT $\left.\times f_{4}\right)+\left(\text { CHIK } \times f_{3}\right)^{\prime}+\left(E_{G G \times f}\right)+\left(\right.$ DAI $\left.\left.\times f_{7}\right)\right]$ & 27.14 \\
\hline 6 & Int. $^{\mathrm{c}}+\left[\left(\right.\right.$ FRU $\left.\times \mathrm{f}_{9}\right)+\left(\right.$ VEG $\left.\times \mathrm{f}_{9}\right)+\left(\mathrm{RMT} \times \mathrm{f}_{4}\right)+\left(\mathrm{CHIK} \times \mathrm{f}_{3}\right)+\left(\mathrm{EGG} \times \mathrm{f}_{4}\right)+\left(\right.$ DAI $\left.\left.\times \mathrm{f}_{7}\right)\right]$ & 22.44 \\
\hline 7 & Int. $^{c}+\left[\left(\right.\right.$ FRU $\left.\times f_{10}\right)+\left(\right.$ VEG $\left.\times f_{10}\right)+\left(\right.$ RMT $\left.\times f_{3}\right)+\left(\right.$ CHIK $\left.\times f_{3}\right)+\left(E G G \times f_{4}\right)+\left(\right.$ DAI $\left.\left.\times f_{7}\right)\right]$ & 9.76 \\
\hline 8 & Int. $^{c}+\left[\left(\right.\right.$ FRU $\left.\times f_{11}\right)+\left(\right.$ VEG $\left.\times f_{10}\right)+\left(\right.$ RMT $\left.\times f_{3}\right)+\left(\right.$ CHIK $\left.\times f_{3}\right)+\left(E G G \times f_{4}\right)+\left(\right.$ DAI $\left.\left.\times f_{7}\right)\right]$ & 4.58 \\
\hline 9 & Int. $^{c}+\left[\left(\right.\right.$ FRU $\left.\times f_{12}\right)+\left(\right.$ VEG $\left.\times f_{11}\right)+\left(\right.$ RMT $\left.\times f_{3}\right)+\left(\right.$ CHIK $\left.\times f_{3}\right)+\left(E G G \times f_{4}\right)+\left(\right.$ DAI $\left.\left.\times f_{7}\right)\right]$ & -5.64 \\
\hline 10 & 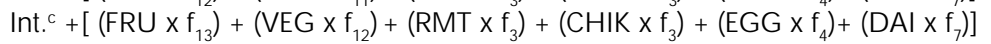 & -6.71 \\
\hline
\end{tabular}

a Regression coefficients $\left(\beta_{1}\right)$ after adjusted for food frequency consumption of food and food groups obtained from Table 3 .

b Calculated by assuming changes in serum low density lipoprotein levels (mg/dl).

c Intercept $\left(\beta_{0}\right)=44.40$

FRU: fruits. VEG : vegetables. RMT: red meats. CHIK: chicken. EGG: eggs. DAI: dairy 
to be positively related to CHD incidence. Diet has a direct effect on the cholesterol level of the beta-lipoproteins seen in the blood plasma. Many laboratory and population studies suggested that saturated fats increase plasma cholesterol and LDL-C levels., ${ }^{3,21}$ Some of the major sources of saturated fats are meat, animal fat, and dairy products.

Ness and Powles, ${ }^{15}$ in a review of the risks for cardiovascular disease, found a significant protective association with fruit and vegetables consumption. In this cross-sectional study, fruits and vegetables consumption was associated with a favorable lipidic profile, whereas an inverse association was seen for meat and dairy products. These associations persisted after adjustment for age, gender, physical activity, body mass index, waist-to-hip ratio and others potential confounding factors, and are likely to reflect the causal effect of dietary fats on blood lipids concentration in experimental studies. Thorogood et al, ${ }^{20}$ observed the same effect; those individuals on a meat diet showed higher LDL-C levels than the ones who did not consume meat. Data from the Coronary Artery Risk Development in Young Adults (CARDIA) showed a positive relationship between meat consumption and LDL-C levels. ${ }^{19}$ A positive relationship between total cholesterol and meat and dairy consumption was confirmed in a cohort study by Appleby et $\mathrm{al}^{2}$ Jacobsen \& Thelle $^{10}$ showed a positive association between dairy products consumption and lipids levels.

Regarding bean consumption, a significant negative association with serum LDL-C levels was not found and there was a significant inverse relationship with HDL-C. In contrast, Glore et $\mathrm{al}^{8}{ }^{8}$ in a review study, emphasized the significant lipid-lowering effect of soluble fibers. Also Anderson et al ${ }^{1}$ confirmed the same effect with beans consumption. These findings could be explained by the fact that most people seasoned the beans with bacon in their preparation.

Regarding fish consumption, there was not a significant inverse association between fish consumption and serum lipids as found by Bolton-Smith et al. ${ }^{5}$ One possible explanation could be the very low consumption of fish.

In the present study alcohol consumption was significantly positively associated with HDL-C, as was observed by Bolton-Smith et $\mathrm{al}^{5}$ and confirmed by Rimm et al. ${ }^{17}$ This association was not found by Bertolami et $\mathrm{al},{ }^{4}$ in a study carried out Brazil. Only few diet studies have been performed with Brazilian population to observe the relationship between food consumption and serum lipids levels.

The study data allowed to generate an hypothetical diet showing a substantial reduction in LDL-C level $(-16 \mathrm{mg} / \mathrm{dl})$, obtained by increasing the serving size in fruits and vegetables consumption nine and eight times, respectively, and decreasing red meat and chicken consumption by half. Also a reduction in LDL-C was achieved by modifying diet fat intake in Clevidence et al study. ${ }^{6}$

This study offers support to the perception that food consumption is an important determinant of the population lipidic profile. Food consumption of animal products increases serum LDL-C, while fruits and vegetables decrease it. These products have to be considered when the effect of dietary cholesterol, saturated fat and fibers is evaluated. Further studies are needed to identify dietary patterns of Brazilian population to develop regional and national prevention and control programs.

In this Brazilian population, dietary habits seem to contribute substantially to variation in blood LDL-C and HDL-C concentrations. Substantially reductions in the CHD risk could be achieved by dietary changes.

\section{REFEREN CES}

1. Anderson JW, Story L, Sieling B, Chen W L, Petro MS, Story J. Hypocholesterolemic effects of oat-bran or bean intake for hypercholesterolemic men. Am J Clin N utr 1994;40:1146-55.

2. Appleby PN, Thorogood M, MCPherson K, Mann JI. Associations between plasma lipid concentration and dietary, lifestyle and physical factors in the 0 xford Vegetarian Study. J Hum Nutr Diet 1995;8:305-14.

3. Ascherio A, Rimm EB, Giovannucci EL, Spiegelman D, Stampfer M, Willett WC. Dietary fat and risk of coronary heart disease in men: cohort follow up study in the U nited States. Br M ed J 1996;313:84-90.

4. Bertolami MC, Faludi AA, Latorre $M$ do RDO, Zaidan FOT. Perfil lipídico de funcionários de indústria metalúrgica e sua relação com outros fatores de risco. Arq Bras Cardiol 1993;60:293-9.

5. Bolton-Smith C, Woodward M, Smith WCS, TunstallPedoe $\mathrm{H}$. Dietary and non-dietary predictors of serum total and HDL-Cholesterol in men and women: results from The Scottish Heart Health Study. Int J Epidemiol 1991;20:95-104. 
6. Clevidence BA, Judd JT, Schatzkin A, Muesing RA, Campbell WS, Brown CC, et al. Plasma lipid and lipoprotein concentrations of men consuming a low-fat, high-fiber diet. Am J Clin N utr 1992;55:689-94.

7. Fornés NS. Padrões alimentares e suas relações com os lipídios séricos em população da área metropolitana de São Paulo [tese]. São Paulo: Faculdade de Saúde Pública da USP; 1998.

8. Glore SR, Van Treeck D, Knehans AW, Guild M. Soluble fiber and serum lipids: a literature review. J Am Diet Assoc 1994;94:425-36.

9. Groen JJ, Bologh M, Yaron E, Freeman J. Influence of the nature of the fat in diets high in carbohydrate (mainly derived from bread) on the serum cholesterol. Am J Clin Nutr 1965;17:296-304.

10. Jacobsen BK, Thelle DS. The Tromsø Heart Study: food habits, serum total cholesterol, HDL-cholesterol, and triglycerides. Am J Epidemiol 1987;125:622-30.

11. Lotufo PA. A mortalidade precoce por doenças crônicas nas capitais de regiões metropolitanas do Brasil [tese]. São Paulo: Faculdade de Saúde Pública da USP; 1995.

12. Martins IS, Coelho LT, Mazzilli RN, Singer JM, Souza CU, Antonieto JRAE, et al. Doenças cardiovasculares ateroscleróticas, dislipidemias, hipertensão, obesidade e diabetes melito em população da área metropolitana da região sudeste do Brasil. I - M etodologia da pesquisa. Rev Saúde Pública 1993;27:250-61.

13. Masur J, Capriglione MJ, Monteiro MG, Jorge MR. Detecção precoce do alcoolismo em clínica médica através do questionário CAGE. J Bras Psiquiatr 1985;34:31-4.
14. M onteiro CA, M ondini L, de Souza ALM, Popkin BM The nutrition transition in Brazil. Eur J Clin N utr 1995;49:105-13.

15. Ness AR, Powles JW. Fruit and vegetables, and cardiovascular disease: a review. Int J Epidemiol 1997;26:1-13.

16. O rganización Mundial de la Salud. Reunión Consultiva Conjunta FAO/OMS/U NU de Expertos sobre Necesidades de Energía y de Proteínas, Ginebra. Informe. Ginebra; 1985. [O MS - Serie de Informes Técnicos; 724].

17. Rimm EB, Giovannucci EL, Willett WC, Coldit GA, Ascherio A, Rosner B, et al. Prospective study of alcohol consumption and risk of coronary disease in men. Lancet 1991;338:464-8.

18. Singer J, Cordani L, Latif S. Relatório de análise estatística sobre o projeto "Estudos da relação entre doenças cardiovasculares ateroscleróticas, dislipidemias, hipertensão, obesidade e diabetes melito com fatores de risco". São Paulo: Instituto de Matemática e Estatística da USP; 1990. [SEA - Relatório de Análise Estatística; 9002].

19. Slattery ML, Jacobs DR, Hilner JE, Caan BJ, Van Horn L, Bragg $C$, et al. M eat comsumption and its associations with other diet and health factors in young adults: the CARDIA Study. Am J Clin N utr 1991;54:930-5.

20. Thorogood M, Carter R, Benfield L, McPherson K, Mann Jl. Plasma lipids and lipoprotein cholesterol concentrations in people with different diets in Britain. $\mathrm{Br}$ Med J 1987;295:351-3.

21. Willett W C. Nutritional epidemiology. New York: Oxford University Press; 1998. 


\section{Revista de Saúde Pública Volume 34(4), 2000}

Tabela 3/ Table 3 - Página/ Page 384

Os valores da segunda e terceira coluna da Tabela 3 foram copiados por engano da Tabela 4. Substituir a Tabela conforme a seguir / Values of the second and third columns on Table 3 were miscopied from Table 4. Please replace the Table as follows:

Tabela 3 antiga/ Former Table 3:

\begin{tabular}{|c|c|c|c|}
\hline \multirow[b]{2}{*}{$\begin{array}{l}\text { Food and } \\
\text { food Groups }\end{array}$} & \multicolumn{2}{|c|}{$\begin{array}{l}\text { HDL-Cholesterol } \\
\text { (mg/dl) }\end{array}$} & \multirow[b]{2}{*}{$\begin{array}{l}\text { Multivariate - } \\
\text { simultaneous }\end{array}$} \\
\hline & $\begin{array}{l}\text { Age - Sex } \\
\text { adjusted }\end{array}$ & Multivariate $^{a}$ & \\
\hline \multirow[t]{2}{*}{ Dairy } & $4.86^{* *}$ & -0.57 & -0.31 \\
\hline & (1.57 to 8.15$)$ & $(-1.62$ to 0.52$)$ & $(-1.39$ to 0.77$)$ \\
\hline Fruits & -5.49 & -0.17 & -0.13 \\
\hline \multirow{2}{*}{ Vegetable } & $\begin{array}{c}(-9.61 \text { to }-1.37) \\
-3.21^{-1 .}\end{array}$ & $\begin{array}{c}(-1.48 \text { to } 1.14) \\
-0.25\end{array}$ & $(-1.48$ to 1.22$)$ \\
\hline & $(-5.61$ to -0.82$)$ & $(-1.04$ to 0.46$)$ & $(-0.79$ to 0.81$)$ \\
\hline \multirow[t]{2}{*}{ Red meat } & 10.69 & 0.26 & 0.25 \\
\hline & $\begin{array}{c}(6.75 \text { to } 14.63) \\
18.08^{* . *}\end{array}$ & $\begin{array}{c}(-0.99 \text { to } 1.51) \\
-105\end{array}$ & $(-0.99$ to 1.49$)$ \\
\hline Chicken & (8.67 to 27.49 ) & $(-3.94$ to 1.84$)$ & $\begin{array}{c}-0.56 \\
(-3.44 \text { to } 2.32)\end{array}$ \\
\hline Eggs & 6.08 & -1.45 & -1.39 \\
\hline \multirow{2}{*}{ Processed Meat } & $\begin{array}{c}\text { (1.01 to } 11.15) \\
19.66^{*}\end{array}$ & $\begin{array}{c}(-3.03 \text { to } 0.13) \\
-2.06\end{array}$ & $\begin{array}{c}(-2.97 \text { to } 0.19) \\
-2.67\end{array}$ \\
\hline & (7.40 to 31.92$)$ & $(-5.81$ to 1.69$)$ & $(-6.44$ to 1.10$)$ \\
\hline Fish & $\begin{array}{c}-16.55 \\
(-41.61 \text { to } 8.51)\end{array}$ & $\begin{array}{c}-3.09 \\
(-10.72 \text { to } 4.54)\end{array}$ & $\begin{array}{c}-4.75 \\
(-12.38 \text { to } 2.88)\end{array}$ \\
\hline Cereals-Bread & 0.36 & $-1.07^{\circ}$ & -0.65 \\
\hline \multirow[t]{2}{*}{ Beans } & $\begin{array}{c}(-2.44 \text { to } 3.16) \\
-2.21\end{array}$ & $\begin{array}{c}(-1.94 \text { to }-0.20) \\
-3.33^{* .}\end{array}$ & $(-1.56$ to 0.26$)$ \\
\hline & $(-9.61$ to 5.19$)$ & $(-5.61$ to -1.05$)$ & $(-5.57$ to -0.87$)$ \\
\hline Alcohol Beverage & $\begin{array}{c}-2.48 \\
(-9.44 \text { to } 4.48)\end{array}$ & $\begin{array}{c}6.95 \\
(4.32 \text { to } 9.58)\end{array}$ & $\begin{array}{c}7.23 \\
(4.59 \text { to } 9.87)\end{array}$ \\
\hline
\end{tabular}

a Model includes age (continuous variable); sex (male=1); body mass index/standard deviation (continuous variable); waist to hip ratio/standard deviation (continuous variable); educational level (five categories); family income (four categories); physical activity (three categories); smoking habits (smoker $\geq 10$ cigarettes per day); Ethylism (alcoholic by CAGE questionnaire ${ }^{13}$ ). • Additionally adjusted for food frequency consumption of food and food groups (continuous variable).

${ }^{*} \mathrm{p} \leq .05 ;{ }^{\star \star} \mathrm{p} \leq .01 ;{ }^{* \star \star} \mathrm{p} \leq .001$

Tabela 3 atual/ Correct Table 3:

Table 3 - Regression coefficients - $\beta_{1}$ (95\% confidence interval) of food frequency consumption of food groups in linear models with LDL-Cholesterol as dependent variable.

\begin{tabular}{|c|c|c|c|}
\hline $\begin{array}{l}\text { Food and } \\
\text { food Groups }\end{array}$ & $\begin{array}{l}\text { Age - Sex } \\
\text { adjusted }\end{array}$ & $\begin{array}{c}\text { LDL-Cholesterol (mg/dl) } \\
\text { Multivariate }\end{array}$ & $\begin{array}{l}\text { Multivariate - } \\
\text { Simultaneous }\end{array}$ \\
\hline Dairy & $\begin{array}{c}4.86 * * \\
(1.57 \text { to } 815)\end{array}$ & $\begin{array}{c}4.33^{*} \\
(0.93 \text { to } 73)\end{array}$ & $\begin{array}{c}4.64 * * \\
(19 \text { to } 8.09)\end{array}$ \\
\hline Fruits & $-5.49 * *$ & $-5.59 * *$ & $-5.18^{*}$ \\
\hline Vegetable & $-3.21 * *$ & $\begin{array}{c}(-9.11 \\
-4.33 * * *\end{array}$ & $\begin{array}{l}(-9.4100-0.95) \\
-5.47 * * *\end{array}$ \\
\hline & $(-5.61$ to -0.82$)$ & $(-6.78$ to -1.88$)$ & $(-8.02$ to -2.92$)$ \\
\hline Red Meat & $\begin{array}{c}10.69 * * * \\
(6.75 \text { to } 14.63)\end{array}$ & $\begin{array}{c}10.52^{* * *} \\
(6.51 \text { to } 14.53)\end{array}$ & $\begin{array}{c}11.05^{* * *} \\
(7.08 \text { to } 15.02)\end{array}$ \\
\hline Chicken & $18.08 * * *$ & $13.67 * *$ & $14.47 * *$ \\
\hline Eggs & $\begin{array}{c}6.08^{*} \\
\end{array}$ & $\begin{array}{c}5.30^{*} \\
\end{array}$ & $\begin{array}{c}(0 . \angle 8(0) 82 * 00) \\
5.82^{*}\end{array}$ \\
\hline Processed Meat & $\begin{array}{c}(1.01 \text { to } 11.15) \\
19.66^{* *}\end{array}$ & $\begin{array}{c}(0.16 \text { to } 10.44) \\
17.11 * *\end{array}$ & $\begin{array}{c}(0.74 \text { to } 10.90) \\
165 * *\end{array}$ \\
\hline 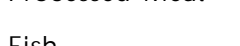 & (7.40 to 31.92$)$ & (4.93 to 29.29 ) & (4.46 to 28.64$)$ \\
\hline Fish & $\begin{array}{c}-16.55 \\
(-41.61 \text { to } 8.51)\end{array}$ & $(-39.30$ to 10.44$)$ & $\begin{array}{l}-9.80 \\
(-34.25 \text { to } 14.65)\end{array}$ \\
\hline Cereals-Bread & $\begin{array}{c}0.36 \\
(-244 \text { to } 316)\end{array}$ & $-20^{-0.06}$ & $\left(-40^{-1.14}\right.$ \\
\hline Beans & -2.21 & -1.51 & -1.94 \\
\hline Alcohol Beverage & $\begin{array}{c}-2.48 \\
(-9.44 \text { to } 4.48)\end{array}$ & $\begin{array}{c}(-8.90 \\
-0.36 \\
(-9.07 \text { to } 8.35)\end{array}$ & $\begin{array}{c}-2.40 \\
(-10.86 \text { to } 6.06)\end{array}$ \\
\hline
\end{tabular}

a Model includes age (continuous variable); sex (male=1); body mass index/standard deviation (continuous variable); waist to hip ratio/standard deviation (continuous variable); educational level (five categories); family income (four categories); physical activity (three categories); smoking habits (smoker $=>10$ cigarettes per day); Ethylism (alcoholic by CAGE questionnaire ${ }^{13}$ ).

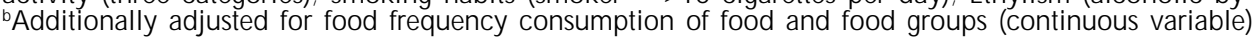

${ }^{*} \mathrm{p} \leq .05 ;{ }^{* *} \mathrm{p} \leq .01 ;{ }^{* * *} \mathrm{p} \leq .001$ 
This article has received corrections in agreement with the ERRATUM published in Volume 40 Number 3. 